\title{
PENGARUH MEKANISME GOOD CORPORATE GOVERNANCE TERHADAP MANAJEMEN LABA
}

\author{
Dwi Urip Wardoyo, Rekha Fakhriyah, Risca Amelia \\ Telkom University Bandung Jawa Barat, Indonesia \\ Email: dwiurip@telkomuniversity.ac.id, \\ fakhriyahrekha@student.telkomuniversity.ac.id, \\ riscaameliaa@student.telkomuniversity.ac.id
}

\begin{abstract}
Abstrak
Salah satu informasi yang paling penting dalam pelaporan keuangan suatu perusahaan adalah informasi mengenai laba. Pengguna laporan keuangan dapat mengetahui sejauh mana perusahaan telah melakukan aktivitas nilai tambah melalui informasi laba. Kinerja perusahaan dapat dilihat juga dari informasi laba perusahaan untuk dijadikan sebagai bahan pertimbangan dalam membuat keputusan. Dengan adanya dampak yang signifikan dari laba, maka manajemen perusahaan akan berusaha untuk mengelola laba yang dilaporkan. Penelitian ini bertujuan untuk mengetahui faktor apa saja yang dapat mempengaruhi manajemen laba. Metode yang digunakan dalam penelitian ini adalah dengan metode tinjauan atau review yang terstruktur sehingga dapat mengidentifikasi faktor apa saja yang dapat mempengaruhi manajemen laba. Metode dalam pencarian sumber data artikel dilakukan melalui Google Scholar (2019-2021) yang menyediakan artikel karya tulis ilmiah yang relevan sesuai dengan penelitian ini. Berdasarkan hasil literatur review dari 30 artikel atau jurnal mengungkapkan bahwa good corporate governance berpengaruh negatif atau tidak signifikan terhadap manajemen laba.
\end{abstract}

Kata Kunci: good corporate governance; manajemen laba; mekanisme good corporate governance

\section{Abstract}

One of the most important information in the financial reporting of a company is information about earnings. Users of financial statements can find out the extent to which the company has carried out value-added activities through profit information. The company's performance can also be seen from the company's profit information to be taken into consideration in making decisions. With a significant impact on earnings, the company's management will try to manage reported earnings. This study aims to determine what factors can affect earnings management. The method used in this study is a structured review or review method so that it can identify any factors that can affect earnings management. The method insearching for article data sources is done through Google Scholar (2019 - 2021) which provides relevant scientific writing articles according to this research. Based on the results of a literature review of 30 articles or journals revealed that good corporate governance has a negative or insignificant effect on earnings management.

$\begin{array}{ll}\text { How to cite: } & \text { Wardoyo, D, U., Fakhriyah, R., \& Amelia, R., (2021) Pengaruh Mekanisme Good Corporate } \\ & \text { Governance Terhadap Manajemen Laba, Syntax Idea, 3(12), https://doi.org/10.36418/syntax- } \\ & \text { idea.v3i12.1663 } \\ \text { E-ISSN: } & \text { 2684-883X } \\ \text { Published by: } & \text { Ridwan Institute }\end{array}$


Keywords: good corporate governance; earnings Management; good corporate governance mechanism

Received: 2021-11-22; Accepted: 2021-12-05; Published: 2021-12-20

\section{Pendahuluan}

Laporan keuangan adalah laporan aktivitas mengenai kondisi keuangan dari suatu perusahaan dalam suatu periode. Laporan keuangan itu dibuat oleh manajemen perusahaan dengan maksud mempertanggungjawabkan kewajban yang diberikan kepada manajemen oleh para pemilik perusahaan. Kegunaan lain dari laporan keuangan yaitu digunakan untuk memberikan laporan atau informasi tentang kondisi keuangan perusahaan kepada pihak luar. Informasi yang ingin diketahui oleh pihak luar perusahaan salah satunya adalah mengenai laba dan bagaimana laba itu diperoleh. Laba adalah salah satu elemen penting dalam laporan keuangan. Laba yang lebih tinggi dari periode sebelumnya mengisyaratkan bahwa kinerja perusahaan telah lebih baik. Informasi laba membantu pemilik perusahaan atau pihak lain memperkirakan earning power perusahaan di masa yang akan datang. Hal yang menjadi target rekayasa tindakan oportunis manajemen untuk memaksimalkan kepuasaannya dalam membuat informasi laba. Tindakan tersebut dapat merugikan pemegang saham atau investor. Laba perusahaan itu dapat diatur dengan cara memilih kebijakan akuntansi tertentu, sehingga laba dapat diatur sesuai dengan kebutuhan perusahaan. Perilaku manajemen dalam mengatur laba sesuai kebutuhan ini disebut dengan istilah manajemen laba (Rahmawati, Dewi, \& Hikmah, 2017).

Manajemen perusahaan dalam melakukan praktik manajemen laba sering kali terjadi karena adanya perbedaan kepentingan antara manajemen dan pemilik perusahaan. Kepentingan yang dimiliki oleh manajemen adalah untuk mendapatkan kompensasi dari kontrak semaksimal mungkin seperti bonus, sementara pemegang saham mengharapkan perkembangan modal yang ditanam. Di zaman ini, praktik manajemen laba seolah-olah sudah menjadi budaya yang biasa dan sering di praktikan di berbagai perusahaan di dunia. Dunia memandang manajemen laba seolah-olah menjadi pelaku korupsi, kolusi, dan berbagai penyimpangan lain yang bisa merugikan publik atas kecurangan yang dilakukan oleh suatu manajer di suatu perusahaan tertentu. Publik berpendapat bahwa informasi yang diinformasikan itu hanya akal-akalan saja demi menguntungkan pihak tertentu (Fadhilia, 2017).

Lemahnya penerapan good corporate governance merupakan salah satu alasan terjadinya praktik manajemen laba. Good corporate governance adalah suatu struktur yang membantu memastikan bahwa manajemen memanfaatkan sumber daya perusahaan dengan baik untuk keperluan semua pihak secara adil serta melaporkan kondisi kinerja keuangan dan operasi kinerja perusahaan. Good corporate governance dapat dijadikan sebagai penentu apakah manajemen perusahaan akan terlibat dalam tindakan manajemen laba atau tidak. Lemahnya penerapan Good corporate governance ini sering dikaitkan atau dilibatkan dengan praktik manajemen laba yang lebih besar. Adanya 
tindakan-tindakan yang mementingkan kepentingan dan kesejahteraannya sendiri dan mengabaikan kepentingan investor merupakan ciri utama dari lemahnya good corporate governance perusahaan. Apabila para manajer perusahaan melakukan tindakan mementingkan kepentingan dan kesejahteraannya sendiri dan mengabaikan kepentingan investor, maka akan menyebabkan gagalnya harapan para investor tentang return atas investasi yang telah mereka tanamkan pada perusahaan. Penerapan Good corporate governance ini memiliki peran penting dalam meyakinkan para investor bahwa manajemen perusahaan tidak bertindak hanya untuk memenuhi kepentingan pribadi pada modal yang ditanamkan, tetapi penerapan Good corporate governance juga dapat membantu meningkatkan kualitas pekerjaan karyawan sehingga berdampak pada kinerja perusahaan secara menyeluruh (Yuni Kartika, 2020). Tujuan penelitian ini secara umum yaitu untuk mengetahui praktik manajemen laba yang dilakukan perusahaan. Sedangkan secara khusus adalah untuk menilai apakah komponen GCG memiliki pengaruh pada manajemen laba. Adapun rumusan masalah penelitian.

\section{Metode Penelitian}

Penelitian ini menggunakan metode literatur review atau tinajuan yang secara terstruktur untuk mengidentifikasi bagaimana pengaruh good corporate governance terhadap manajemen laba. Ada dua kriteria yang digunakan dalam melakukan penelitian ini yaitu kriteria inklusi dan kriteria eksklusi. Mekanisme good good corporate governance terhadap manajemen laba merupakan kriteria inklusi, sedangkan berbagai artikel atau jurnal yang tidak menggunakan Bahasa Inggris merupakan kriteria eksklusi. Penelitian ini mengakses dan menggunakan Google Scholar sebagai sarana untuk mengumpulkan berbagai jurnal yang sesuai dengan kata kunci good corporate governance terhadap manajemen laba (Ramadhani, Sari, \& Darlis, 2015). Artikel dapat dilakukan pemeriksaan apabila artikel itu memenuhi kriteria inklusi dan eksklusi. Artikel atau jurnal yang dijadikan referensi diambil pada tahun 2020 sampai tahun 2021. Berdasarkan hal tersebut, terdapat 20 artikel yang memenuhi dari kriteria inklusi dan eksklusi.

\section{Hasil dan Pembahasan}

Berdasarkan hasil pemeriksaan atau analisis dari 30 artikel yang sudah sesuai dengan tujuan penelitian ini, kami melakukan pengelompokan atas artikel yang dianalisis berupa ringkasan data yang terdiri dari penulis artikel, judul penelitian, tujuan penelitian, metode penelitian, dan hasil penelitian. Adapaun hasil ringkasan data artikel dapat dilihat di Tabel 1.

\section{Tabel 1}

\section{Ringkasan Data Artikel}

\begin{tabular}{|c|c|c|c|c|c|}
\hline No & Penulis/Tahun & $\begin{array}{l}\text { Judul } \\
\text { Artikel }\end{array}$ & $\begin{array}{c}\text { Tujuan } \\
\text { Penelitian }\end{array}$ & $\begin{array}{c}\text { Metode } \\
\text { Penelitian }\end{array}$ & Hasil Penelitian \\
\hline 1 & $\begin{array}{l}\text { Ellita Pramesti, } \\
\text { Yuliastuti }\end{array}$ & $\begin{array}{l}\text { Pengaruh } \\
\text { Good }\end{array}$ & $\begin{array}{l}\text { untuk } \\
\text { menganalisis }\end{array}$ & $\begin{array}{l}\text { metode } \\
\text { analisis }\end{array}$ & $\begin{array}{l}\text { Tidak } \\
\text { pengaruh }\end{array}$ \\
\hline
\end{tabular}




\begin{tabular}{|c|c|c|c|c|c|}
\hline No & Penulis/Tahun & $\begin{array}{l}\text { Judul } \\
\text { Artikel }\end{array}$ & $\begin{array}{c}\text { Tujuan } \\
\text { Penelitian }\end{array}$ & $\begin{array}{c}\text { Metode } \\
\text { Penelitian }\end{array}$ & Hasil Penelitian \\
\hline & $\begin{array}{lr}\text { Rahayu/ } 2021 \\
\text { (Pramesti \& } \\
\text { Rahayu, 2021). }\end{array}$ & $\begin{array}{l}\text { corporate } \\
\text { governan } \\
\text { ce, } \\
\text { Leverage } \\
\text { dan } \\
\text { Kinerja } \\
\text { Keuangan } \\
\text { Terhadap } \\
\text { Manajemen } \\
\text { laba }\end{array}$ & $\begin{array}{l}\text { pengaruh good } \\
\text { good corporate } \\
\text { governance, } \\
\text { leverage, } \\
\text { kinerja } \\
\text { keuangan } \\
\text { terhadap } \\
\text { manajemen laba. }\end{array}$ & $\begin{array}{l}\text { linier } \\
\text { berganda }\end{array}$ & $\begin{array}{l}\text { good corporate } \\
\text { governance } \\
\text { terhadap } \\
\text { manajemen laba }\end{array}$ \\
\hline 2 & $\begin{array}{l}\text { Putu Indah } \\
\text { Purwanti, Putu } \\
\text { Kepramareni, } \\
\text { Sagung Oka } \\
\text { Pradnyawati/ } \\
2021 \\
\text { (Purwanti, } \\
\text { Kepramareni, } \\
\& \\
\text { Pradnyawati, } \\
\text { 2021). }\end{array}$ & $\begin{array}{l}\text { Pengaruh } \\
\text { Good } \\
\text { corporate } \\
\text { governance } \\
\text {, Ukuran } \\
\text { Perusahaan } \\
\text { Dan } \\
\text { Leverage } \\
\text { Terhadap } \\
\text { Manajemen } \\
\text { Laba Pada } \\
\text { Perusahaan } \\
\text { Manufaktur } \\
\text { Yang } \\
\text { Terdaftar } \\
\text { Di Bursa } \\
\text { Efek } \\
\text { Indonesia } \\
\text { Periode } \\
\text { 2017- } \\
\text { 2019 }\end{array}$ & $\begin{array}{l}\text { untuk menguji } \\
\text { dan } \\
\text { memperoleh } \\
\text { bukti empiris } \\
\text { pengaruh } \\
\text { komposisi } \\
\text { dewan } \\
\text { komisaris } \\
\text { independen, } \\
\text { kepemilikan } \\
\text { institusional, } \\
\text { kepemilikan } \\
\text { manajerial, } \\
\text { ukuran } \\
\text { perusahaan dan } \\
\text { leverage } \\
\text { terhadap } \\
\text { manajemen } \\
\text { laba }\end{array}$ & $\begin{array}{l}\text { analisis } \\
\text { regresi } \\
\text { linier } \\
\text { berganda. }\end{array}$ & $\begin{array}{l}\text { Tidak terdapat } \\
\text { pengaruh antara } \\
\text { good corporate } \\
\text { governance } \\
\text { terhadap } \\
\text { manajemen laba }\end{array}$ \\
\hline 3 & $\begin{array}{l}\text { Melati } \\
\text { Sihombing/ } \\
2021 \\
\text { (Tarigan, } \\
\text { 2021). }\end{array}$ & $\begin{array}{l}\text { Pengaruh } \\
\text { Good Good } \\
\text { corporate } \\
\text { governance } \\
\text { Terhadap } \\
\text { Manajemen } \\
\text { Laba Pada } \\
\text { Perusahaan } \\
\text { Manufaktur } \\
\text { yang } \\
\text { terdaftar di } \\
\text { BEI Tahun } \\
\text { 2013- } \\
\text { 2017. }\end{array}$ & $\begin{array}{l}\text { untuk } \\
\text { mengetahui } \\
\text { apakah } \\
\text { kepemilikan } \\
\text { manajerial, } \\
\text { dewan } \\
\text { komisaris } \\
\text { independen, } \\
\text { dan } \\
\text { kepemilikan } \\
\text { manajerial } \\
\text { berpengaruh } \\
\text { signifikan } \\
\text { secara parsial } \\
\text { dan }\end{array}$ & $\begin{array}{l}\text { metode } \\
\text { purposi } \\
\text { ve } \\
\text { samplin } \\
\text { g. }\end{array}$ & $\begin{array}{l}\text { Terdapat pengaruh } \\
\text { antara } \\
\text { corporate } \\
\text { governance terhadap } \\
\text { manajemen laba }\end{array}$ \\
\hline
\end{tabular}




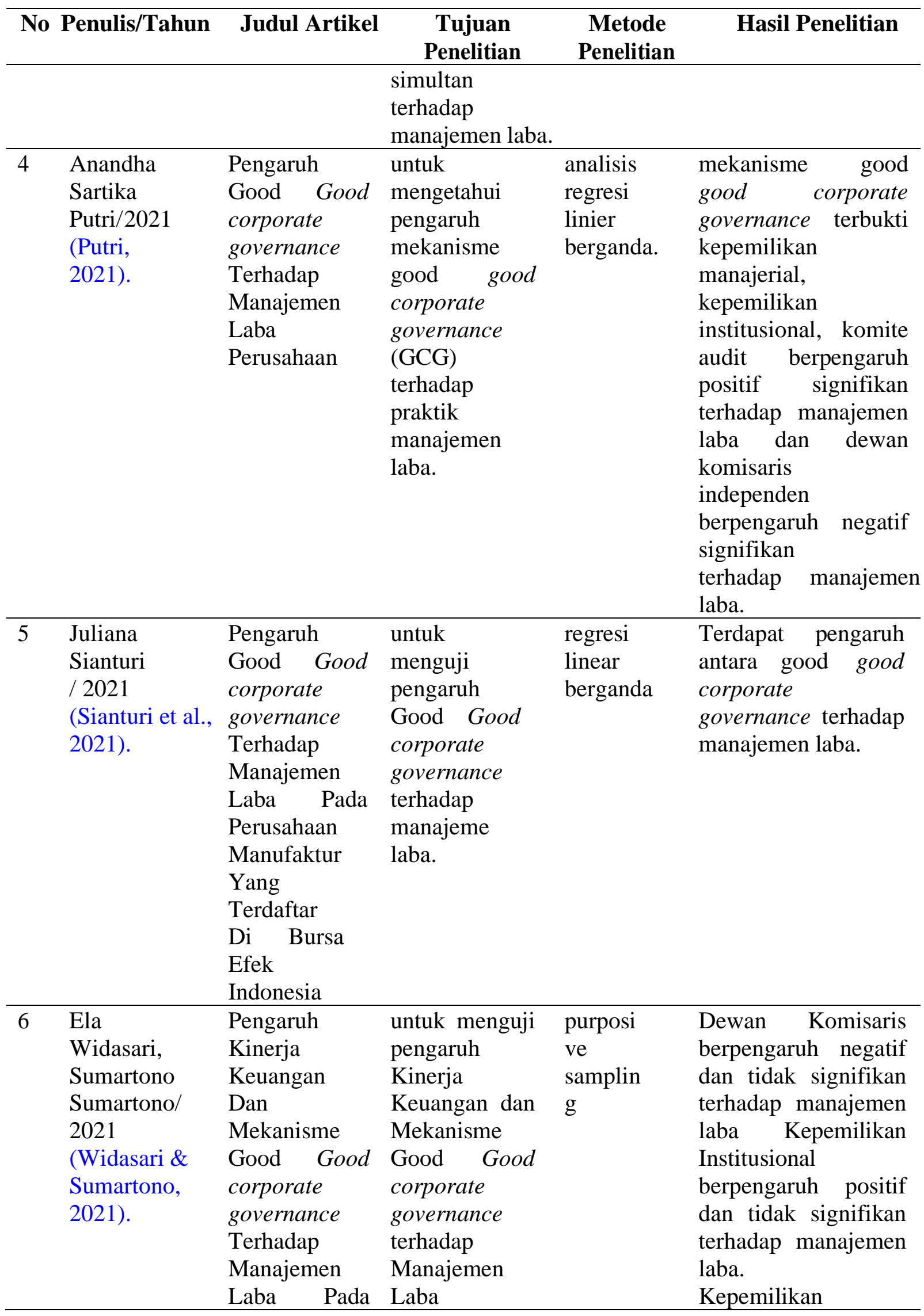




\begin{tabular}{|c|c|c|c|c|c|}
\hline \multirow{2}{*}{\multicolumn{2}{|c|}{ No Penulis/Tahun }} & Judul Artikel & $\begin{array}{c}\text { Tujuan } \\
\text { Penelitian }\end{array}$ & $\begin{array}{c}\text { Metode } \\
\text { Penelitian }\end{array}$ & Hasil Penelitian \\
\hline & & $\begin{array}{l}\text { Perusahaan } \\
\text { Manufaktur } \\
\text { Sektor Barang } \\
\text { Konsumsi } \\
\text { Terdaftar Di } \\
\text { Bursa Efek } \\
\text { Indonesia (Bei) }\end{array}$ & & & $\begin{array}{l}\text { Manajerial } \\
\text { berpengaruh positif } \\
\text { dan signifikan } \\
\text { terhadap manajemen } \\
\text { laba. Komite Audit } \\
\text { berpengaruh positif } \\
\text { dan tidak signifikan } \\
\text { terhadap manajemen } \\
\text { laba. }\end{array}$ \\
\hline 7 & $\begin{array}{l}\text { Lu'luilmaknu } \\
\text { n,Devvy } \\
\text { Rusli/ } 2021 \\
\text { (Lu'luilmakn } \\
\text { un \& Rusli, } \\
\text { 2021). }\end{array}$ & $\begin{array}{l}\text { Pengaruh } \\
\text { Kualitas } \\
\text { Audit Dan } \\
\text { Good } \\
\text { corporate } \\
\text { governance } \\
\text { Terhadap } \\
\text { Manajemen } \\
\text { Laba (Studi } \\
\text { Pada Pa } \\
\text { Perusahaan } \\
\text { Manufaktur } \\
\text { Yang } \\
\text { Terdaftar Di } \\
\text { Bursa Efek } \\
\text { Indonesia } \\
\text { Periode 2015- } \\
\text { 2019) }\end{array}$ & $\begin{array}{l}\text { untuk menguji } \\
\text { dan } \\
\text { memperoleh } \\
\text { bukti empiris } \\
\text { pengaruh } \\
\text { kualitas audit } \\
\text { dan good } \\
\text { corporate } \\
\text { governance } \\
\text { (kepemilikan } \\
\text { institusional, } \\
\text { ukuran dewan } \\
\text { komisaris dan } \\
\text { komite audit) } \\
\text { terhadap } \\
\text { manajemen } \\
\text { laba }\end{array}$ & $\begin{array}{l}\text { metode } \\
\text { analisis } \\
\text { regresi } \\
\text { linear } \\
\text { berganda }\end{array}$ & $\begin{array}{l}\text { kualitas audit } \\
\text { tidak berpengaruh } \\
\text { terhadap } \\
\text { manajemen laba, } \\
\text { sedangkan good } \\
\text { corporate } \\
\text { governance } \\
\text { (kepemilikan } \\
\text { institusional, } \\
\text { ukuran dewan } \\
\text { komisaris dan } \\
\text { komite audit) } \\
\text { berpengaruh } \\
\text { terhadap } \\
\text { manajemen laba. }\end{array}$ \\
\hline
\end{tabular}

\begin{tabular}{|c|c|c|c|c|c|}
\hline No & Penulis/Tahun & $\begin{array}{l}\text { Judul } \\
\text { Artikel }\end{array}$ & $\begin{array}{c}\text { Tujuan } \\
\text { Penelitian }\end{array}$ & $\begin{array}{c}\text { Metode } \\
\text { Penelitian }\end{array}$ & Hasil Penelitian \\
\hline 8 & $\begin{array}{l}\text { Mardianto } \\
\text { Mardianto, } \\
\text { Latycia Carin/ } \\
2021\end{array}$ & $\begin{array}{l}\text { Pengaruh } \\
\text { Tata Kelola } \\
\text { Perusahaan } \\
\text { Terhadap } \\
\text { Manajemen } \\
\text { Laba Pada } \\
\text { Perusahaan } \\
\text { Manufaktur } \\
\text { Yang } \\
\text { Terdaftar } \\
\text { Di Bei } \\
\text { Tahun } \\
\text { 2016-2019 }\end{array}$ & $\begin{array}{l}\text { untuk menguji } \\
\text { pengaruh } \\
\text { karakteristik } \\
\text { dewan direksi } \\
\text { dan komite } \\
\text { audit terhadap } \\
\text { manajemen } \\
\text { laba riil. }\end{array}$ & $\begin{array}{l}\text { Kualitatati } \\
\mathrm{f} \text { Dan } \\
\text { Metode } \\
\text { Purposive } \\
\text { Sampling }\end{array}$ & $\begin{array}{l}\text { Bahwa total empat } \\
\text { karakteristikyang } \\
\text { diukur pada dewan } \\
\text { direksi dan komite } \\
\text { audit tidak } \\
\text { berpengaruh } \\
\text { signifikan terhadap } \\
\text { manajemen labariil. }\end{array}$ \\
\hline 9 & $\begin{array}{l}\text { Mutia } \\
\text { Rahmadani/ } \\
2021\end{array}$ & $\begin{array}{l}\text { Pengaruh } \\
\text { Good Good } \\
\text { corporate }\end{array}$ & $\begin{array}{l}\text { untuk } \\
\text { mengetahui } \\
\text { prediksi }\end{array}$ & $\begin{array}{l}\text { analisis } \\
\text { statistik } \\
\text { deskriptif }\end{array}$ & $\begin{array}{l}\text { good good corporate } \\
\text { governancer yang } \\
\text { diukur menggunakan }\end{array}$ \\
\hline
\end{tabular}




\begin{tabular}{|c|c|c|c|c|c|}
\hline No & Penulis/Tahun & $\begin{array}{l}\text { Judul } \\
\text { Artikel } \\
\end{array}$ & $\begin{array}{c}\text { Tujuan } \\
\text { Penelitian }\end{array}$ & $\begin{array}{c}\text { Metode } \\
\text { Penelitian }\end{array}$ & Hasil Penelitian \\
\hline & & $\begin{array}{l}\text { governance } \\
\text { Konservatis } \\
\text { me } \\
\text { Akuntansi } \\
\text { Dan } \\
\text { Ukuran } \\
\text { Perusahaan } \\
\text { Terhadap } \\
\text { Manajemen } \\
\text { Laba }\end{array}$ & $\begin{array}{l}\text { tindakan } \\
\text { manajemen } \\
\text { laba dalam } \\
\text { pelaporan } \\
\text { keuangan, } \\
\text { dengan } \\
\text { menganalisis } \\
\text { pengaruh good } \\
\text { good corporate } \\
\text { governance, } \\
\text { konservatisme } \\
\text { akuntansi dan } \\
\text { ukuran } \\
\text { perusahaan } \\
\text { terhadap } \\
\text { manajemen laba }\end{array}$ & $\begin{array}{l}\text { dan analisis } \\
\text { statistik } \\
\text { inferensial } \\
\text { menggunak } \\
\text { an model } \\
\text { regresi data } \\
\text { panel. }\end{array}$ & $\begin{array}{l}\text { indeks skoring dan } \\
\text { tidak berpengaruh } \\
\text { signifikan terhadap } \\
\text { manajemen laba, } \\
\text { sedangkan untuk } \\
\text { konservatisme } \\
\text { akuntansi dan ukuran } \\
\text { perusahaan } \\
\text { berpengaruh negatif } \\
\text { terhadap manajemen } \\
\text { laba }\end{array}$ \\
\hline 10 & $\begin{array}{l}\text { Deyan Tiara } \\
\text { Monika, } \\
\text { Karina } \\
\text { Mardhatillah, } \\
\text { Noviyanti } \\
\text { Noviyanti/ } \\
2021\end{array}$ & $\begin{array}{l}\text { Pengaruh } \\
\text { Good Good } \\
\text { corporate } \\
\text { governance } \\
\text { dan } \\
\text { Asimetri } \\
\text { Informasi } \\
\text { Terhadap } \\
\text { Manajemen } \\
\text { Laba (Studi } \\
\text { Empiris } \\
\text { Pada } \\
\text { Perusahaan } \\
\text { Manufaktur } \\
\text { Sektor } \\
\text { Industri } \\
\text { Dasar Dan } \\
\text { Kimia Yang } \\
\text { Terdaftar } \\
\text { Di BEI }\end{array}$ & $\begin{array}{l}\text { untuk } \\
\text { mengetahui } \\
\text { pengaruh good } \\
\text { corporate } \\
\text { governanve } \\
\text { dan asimetri } \\
\text { informasi } \\
\text { terhadap } \\
\text { manajemen } \\
\text { laba. }\end{array}$ & $\begin{array}{l}\text { analisis } \\
\text { regresi } \\
\text { linear } \\
\text { bergada }\end{array}$ & $\begin{array}{l}\text { kepemilikan } \\
\text { institusional, } \\
\text { kepemilikan } \\
\text { manajerial, dewan } \\
\text { komisaris } \\
\text { independen dan } \\
\text { komite audit } \\
\text { berpengaruh positif } \\
\text { tidak signifikan } \\
\text { terhadap manajemen } \\
\text { laba sedangkan } \\
\text { asimetri informasi } \\
\text { berpengaruh negatif } \\
\text { dan tidak signifikan } \\
\text { terhadap manajemen } \\
\text { laba. }\end{array}$ \\
\hline 11 & $\begin{array}{l}\text { Shania } \\
\text { Agustin/ } 2020\end{array}$ & $\begin{array}{l}\text { Pengaruh } \\
\text { Mekanisme } \\
\text { Good Good } \\
\text { corporate } \\
\text { governance } \\
\text { Terhadap } \\
\text { Manajemen } \\
\text { Laba Pada } \\
\text { Perusahaan } \\
\text { Manufaktur } \\
\end{array}$ & $\begin{array}{l}\text { Untuk } \\
\text { mengetahui } \\
\text { pengaruh good } \\
\text { corporate } \\
\text { governance } \\
\text { terhadap } \\
\text { manajemen } \\
\text { laba }\end{array}$ & $\begin{array}{l}\text { analisis } \\
\text { regresi } \\
\text { linier } \\
\text { berganda }\end{array}$ & 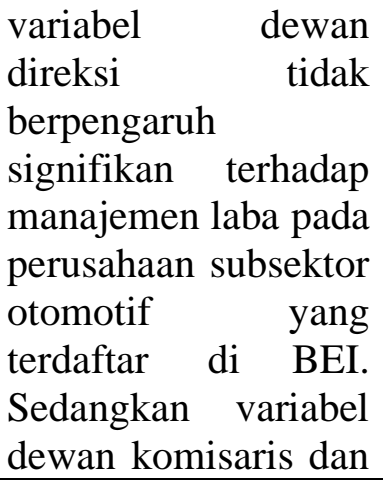 \\
\hline
\end{tabular}




\begin{tabular}{|c|c|c|c|c|c|}
\hline No & Penulis/Tahun & $\begin{array}{l}\text { Judul } \\
\text { Artikel }\end{array}$ & $\begin{array}{c}\text { Tujuan } \\
\text { Penelitian }\end{array}$ & $\begin{array}{c}\text { Metode } \\
\text { Penelitian }\end{array}$ & Hasil Penelitian \\
\hline & & $\begin{array}{l}\text { Subsektor } \\
\text { Otomotif } \\
\text { Yang } \\
\text { Terdaftar } \\
\text { Di Bursa } \\
\text { Efek } \\
\text { Indonesia }\end{array}$ & & & $\begin{array}{l}\text { komite audit } \\
\text { berpengaruh } \\
\text { signifikan terhadap } \\
\text { manajemen laba }\end{array}$ \\
\hline 12 & $\begin{array}{l}\text { Ulfa Santika } \\
\text { Sari, Felisitas } \\
\text { Defung, }\end{array}$ & $\begin{array}{l}\text { Pengaru } \\
\mathrm{h} \\
\text { Leverag } \\
\mathrm{e} \text { dan } \\
\text { Good }\end{array}$ & $\begin{array}{l}\text { ntuk mengetahui } \mathrm{p} \\
\text { pengaruh } \\
\text { leverage dan } \mathrm{s} \\
\text { good }\end{array}$ & $\begin{array}{l}\text { purposi } \\
\text { ve } \\
\text { samplin } \\
\text { g }\end{array}$ & $\begin{array}{l}\text { Good good } \\
\text { corporate } \\
\text { governance } \\
\text { berpengaruh negatif } \\
\text { dan tidak }\end{array}$ \\
\hline & $\begin{array}{l}\text { Maryam Nadi }] \\
2020\end{array}$ & $\begin{array}{l}\text { governance } \\
\text { Terhadap } \\
\text { Manajemen } \\
\text { Laba Pada } \\
\text { Perusahaan } \\
\text { Manufaktur }\end{array}$ & $\begin{array}{l}\text { corporate } \\
\text { governance } \\
\text { terhadap } \\
\text { manajemen laba }\end{array}$ & & $\begin{array}{l}\text { signifikan } \\
\text { terhadap } \\
\text { manajemen } \\
\text { laba. }\end{array}$ \\
\hline 13 & $\begin{array}{l}\text { Inez Yustika } \\
\text { Saraswati, } \\
\text { Mohammad } \\
\text { Kholiq } \\
\text { Mahfud/2020 }\end{array}$ & $\begin{array}{l}\text { Analisis } \\
\text { Pengaruh Good } \\
\text { corporate } \\
\text { governance, } \\
\text { Leverage Dan } \\
\text { Ukuran } \\
\text { Perusahaan } \\
\text { Terhadap } \\
\text { Manajemen } \\
\text { Laba } \\
\text { (Studi Pada } \\
\text { Perusahaan } \\
\text { Manufaktur } \\
\text { Yang Terdaftar } \\
\text { Di Bei Periode } \\
\text { 2014-2018) }\end{array}$ & $\begin{array}{l}\text { untuk menguji } \\
\text { pengaruh good } \\
\text { corporate } \\
\text { governance, } \\
\text { leverage dan firm } \\
\text { size terhada } \\
\text { praktik } \\
\text { manajemen laba. }\end{array}$ & $\begin{array}{l}\text { regresi linie } \\
\text { berganda } \\
\text { p }\end{array}$ & $\begin{array}{l}\text { ier } \text { komisaris } \\
\text { independen, } \\
\text { komite audit, } \\
\text { kepemilikan } \\
\text { manajerial, } \\
\text { leverage, dan ukuran } \\
\text { perusahaan } \\
\text { berpengaruh } \\
\text { signifikan terhadap } \\
\\
\text { manajemen laba }\end{array}$ \\
\hline 14 & $\begin{array}{l}\text { Fadilah } \\
\text { Syafitri/ } 2020\end{array}$ & $\begin{array}{l}\text { Pengaruh Good } \\
\text { Good } \\
\text { corporate } \\
\text { governance, } \\
\text { Profitabilitas } \\
\text { dan }\end{array}$ & $\begin{array}{l}\text { untuk mengetahui } \\
\text { pengaruh } \\
\text { kepemilikan }\end{array}$ & $\begin{array}{l}\text { ui analisis } \\
\text { statistik } \\
\text { deskriptif } \\
\text { dan } \\
\text { analisis }\end{array}$ & $\begin{array}{l}\text { bahwa kepemilikan } \\
\text { manajerial, komite } \\
\text { audit } \\
\text { dan profitabilitas } \\
\text { berpengaruh secara }\end{array}$ \\
\hline
\end{tabular}




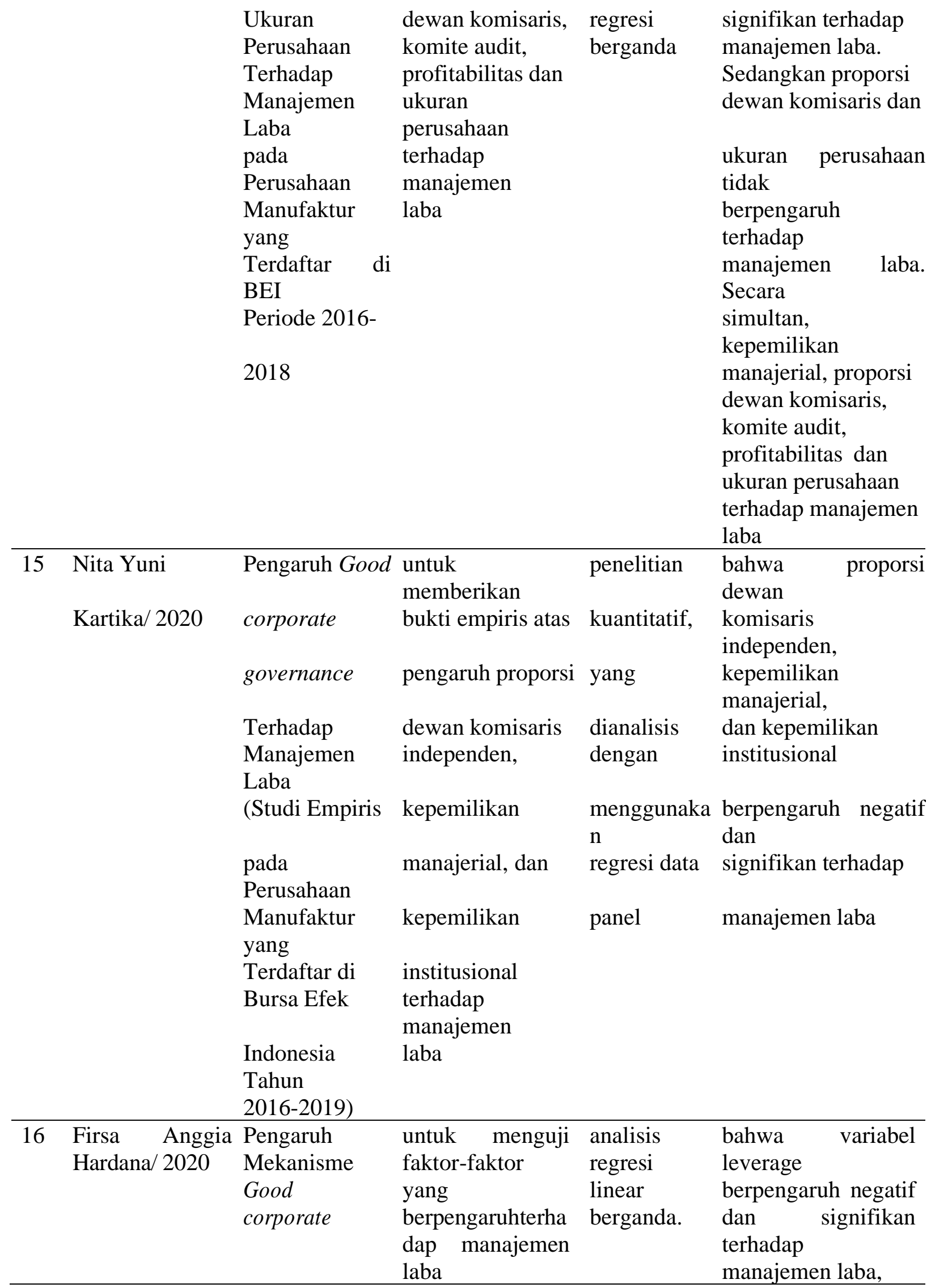




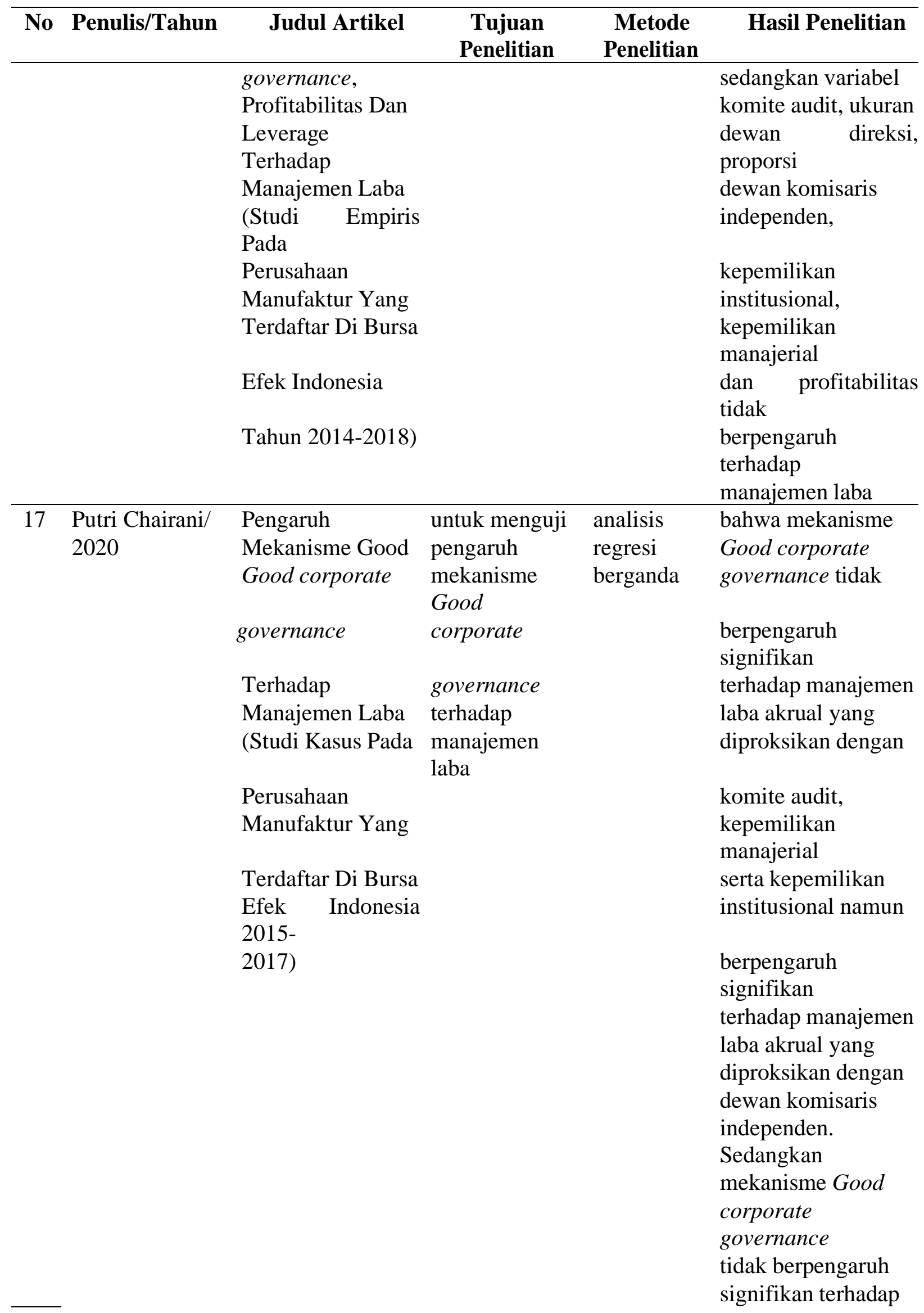




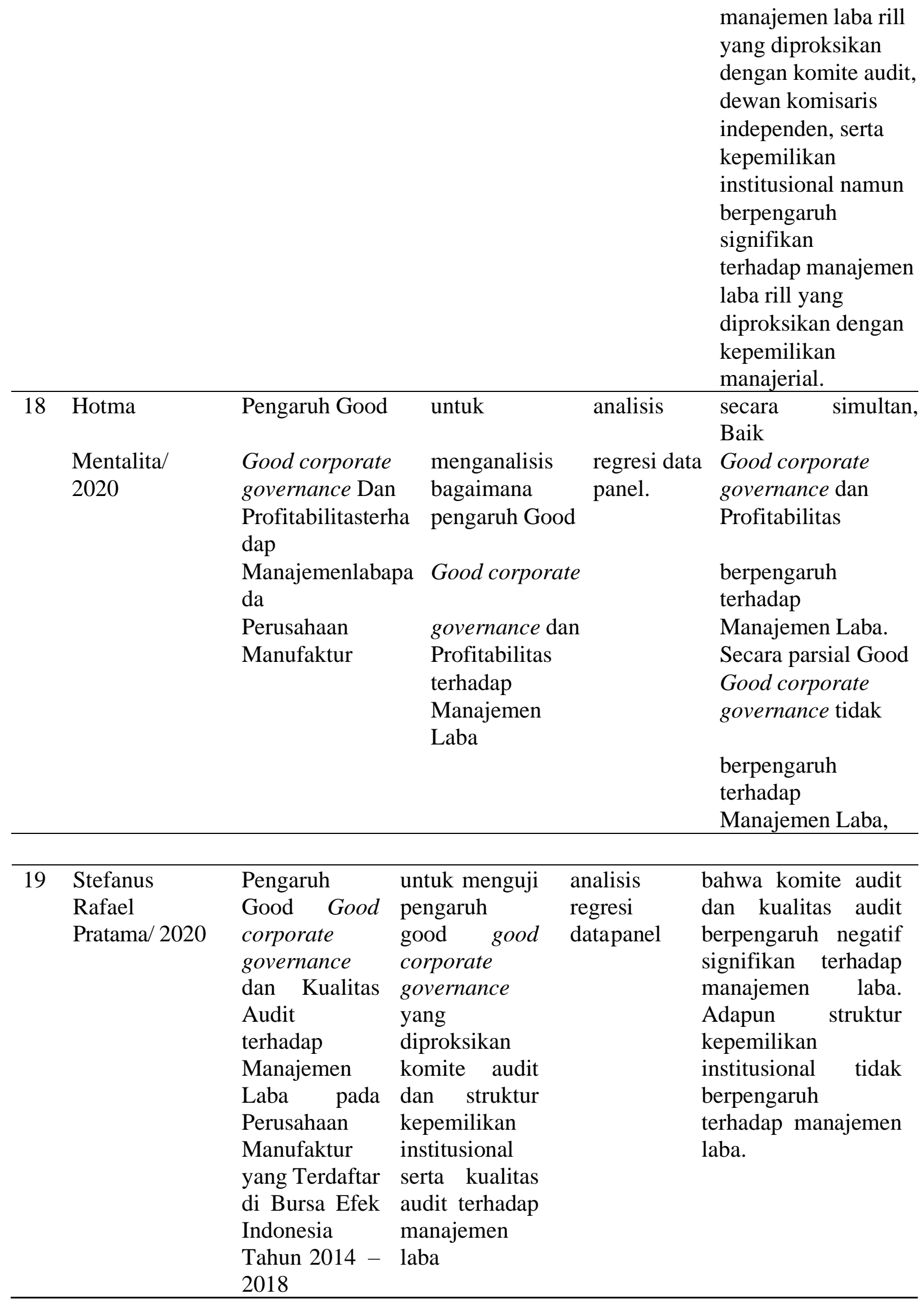




\begin{tabular}{|c|c|c|c|c|c|}
\hline 20 & $\begin{array}{l}\text { Ida Rodunnya/ } \\
2020\end{array}$ & $\begin{array}{l}\text { Pengaruh } \\
\text { Kualitas } \\
\text { Audit Dan } \\
\text { Mekanisme } \\
\text { Good Good } \\
\text { corporate } \\
\text { governance } \\
\text { Terhadap } \\
\text { Aktivitas } \\
\text { Manajemen } \\
\text { Laba (Studi } \\
\text { Empiris Pada } \\
\text { Perusahaan } \\
\text { Manufaktur } \\
\text { Yang } \\
\text { Terdaftar Di } \\
\text { Bei 2015- } \\
\text { 2019) }\end{array}$ & $\begin{array}{l}\text { untuk menguji } \\
\text { dan } \\
\text { menganalisis } \\
\text { pengaruh } \\
\text { kualitas audit } \\
\text { dewan } \\
\text { komisaris } \\
\text { independen, } \\
\text { kepemilikan } \\
\text { manjerial dan } \\
\text { kepemilikan } \\
\text { institusional } \\
\text { terhadap } \\
\text { manajemen } \\
\text { laba }\end{array}$ & $\begin{array}{l}\text { analisis } \\
\text { regresi } \\
\text { linear } \\
\text { berganda. }\end{array}$ & $\begin{array}{l}\text { bahwa kualitas audit } \\
\text { berpengaruh negatif } \\
\text { terhadap manajemen } \\
\text { laba. Dewan } \\
\text { komisaris } \\
\text { independen, } \\
\text { kepemilikan } \\
\text { manajerial dan } \\
\text { kepemilikan } \\
\text { institusional tidak } \\
\text { berpengaruh terhadap } \\
\text { manajemen laba. }\end{array}$ \\
\hline 21 & $\begin{array}{l}\text { Marsheila } \\
\text { Giovani/2019 }\end{array}$ & $\begin{array}{l}\text { Pengaruh } \\
\text { Struktur } \\
\text { Kepemilikan, } \\
\text { Tata Kelola } \\
\text { Perusahaan, } \\
\text { Dan } \\
\text { Karakteristik } \\
\text { Perusahaan } \\
\text { Terhadap } \\
\text { Manajemen } \\
\text { Laba }\end{array}$ & $\begin{array}{l}\text { untuk } \\
\text { mengetahui } \\
\text { pengaruh } \\
\text { struktur } \\
\text { kepemilikan, } \\
\text { tata kelola } \\
\text { perusahaan, dan } \\
\text { karakteristik } \\
\text { perusahaan } \\
\text { dalam praktik } \\
\text { manajemen } \\
\text { laba di } \\
\text { perusahaan } \\
\text { manufaktur } \\
\text { yang terdaftar } \\
\text { di Bursa Efek } \\
\text { Indonesia, yang } \\
\text { dipilih } \\
\text { berdasarkan } \\
\text { metode } \\
\text { purposive } \\
\text { sampling }\end{array}$ & $\begin{array}{l}\text { analisis } \\
\text { regresi } \\
\text { linear } \\
\text { berganda. }\end{array}$ & $\begin{array}{l}\text { Hasil dari analisa } \\
\text { menunjukkan bahwa } \\
\text { kepemilikan } \\
\text { manajerial, ukuran } \\
\text { dewan komisaris, } \\
\text { dan ukuran } \\
\text { perusahaan } \\
\text { mempunyai dampak } \\
\text { negatif signifikan } \\
\text { terhadap kepada } \\
\text { manajemen laba. } \\
\text { Profitabilitas dan } \\
\text { leveragemempunyai } \\
\text { pengaruh positif } \\
\text { terhadap manajemen } \\
\text { laba. } \\
\text { Kepemilikan } \\
\text { institusional, } \\
\text { independensi dewan } \\
\text { komisaris, dan } \\
\text { ukuran komite audit } \\
\text { tidak mempunyai } \\
\text { pengaruh } \\
\text { signidikan } \\
\text { terhadap } \\
\text { manajemen laba }\end{array}$ \\
\hline 22 & $\begin{array}{l}\text { Desri Kristianti } \\
\text { Panjaitan/2019 }\end{array}$ & $\begin{array}{l}\text { Manajemen } \\
\text { Laba: } \\
\text { Ukuran } \\
\text { Perusahaan, }\end{array}$ & $\begin{array}{l}\text { untuk } \\
\text { mengetahui } \\
\text { pengaruh } \\
\text { Ukuran }\end{array}$ & $\begin{array}{l}\text { purposive } \\
\text { sampling } \\
\text { dan analisis } \\
\text { regresi }\end{array}$ & $\begin{array}{l}\text { Hasil penelitian } \\
\text { menunjukkan bahwa } \\
\text { secara simultan } \\
\text { ukuran perusahaan, }\end{array}$ \\
\hline
\end{tabular}




\begin{tabular}{|c|c|c|c|c|}
\hline & $\begin{array}{l}\text { Kepemilika } \\
\text { n Manajerial } \\
\text { dan } \\
\text { Kompensasi } \\
\text { Bonus }\end{array}$ & $\begin{array}{l}\text { Perusahaan, } \\
\text { Kepemilikan } \\
\text { Manajerial dan } \\
\text { Kompensasi } \\
\text { Bonus } \\
\text { terhadap } \\
\text { Manajemen } \\
\text { Laba }\end{array}$ & & $\begin{array}{l}\text { kepemilikan } \\
\text { manajerial dan } \\
\text { kompensasi bonus } \\
\text { berpengaruh } \\
\text { terhadap } \\
\text { manajemen laba. }\end{array}$ \\
\hline & & $\begin{array}{l}\text { pada } \\
\text { Perusahaan } \\
\text { Sektor } \\
\text { Manufaktur } \\
\text { yang terdaftar } \\
\text { di Bursa Efek } \\
\text { Indonesia } \\
\text { Tahun 2014- } \\
2017\end{array}$ & & $\begin{array}{l}\text { Secara parsial } \\
\text { ukuran perusahaan } \\
\text { berpengaruh secara } \\
\text { signifikan dengan } \\
\text { arah } \\
\text { negatif terhadap } \\
\text { manajemen laba, } \\
\text { kompensasi bonus } \\
\text { berpengaruh } \\
\text { secara signifikan } \\
\text { dengan arah positif } \\
\text { terhadap } \\
\text { manajemen laba. } \\
\text { Sedangkan } \\
\text { kepemilikan } \\
\text { manajerial tidak } \\
\text { berpengaruh } \\
\text { signifikan terhadap } \\
\text { manajemen laba. }\end{array}$ \\
\hline 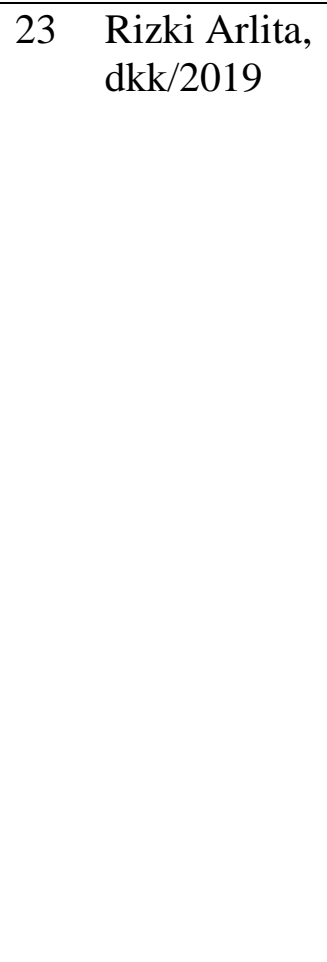 & $\begin{array}{l}\text { Pengaruh } \\
\text { Good Good } \\
\text { corporate } \\
\text { governance } \\
\text { dan } \\
\text { Laverage } \\
\text { Terhadap } \\
\text { Praktik } \\
\text { Manajemen } \\
\text { Laba }\end{array}$ & $\begin{array}{l}\text { untuk menguji } \\
\text { dan } \\
\text { memperoleh } \\
\text { bukti empiris } \\
\text { tentang } \\
\text { pengaruh } \\
\text { good corporate } \\
\text { governance } \\
\text { dan rasio } \\
\text { leverage } \\
\text { terhadap } \\
\text { manajemen laba }\end{array}$ & $\begin{array}{l}\text { metode } \\
\text { analisis } \\
\text { regresi } \\
\text { berganda. }\end{array}$ & 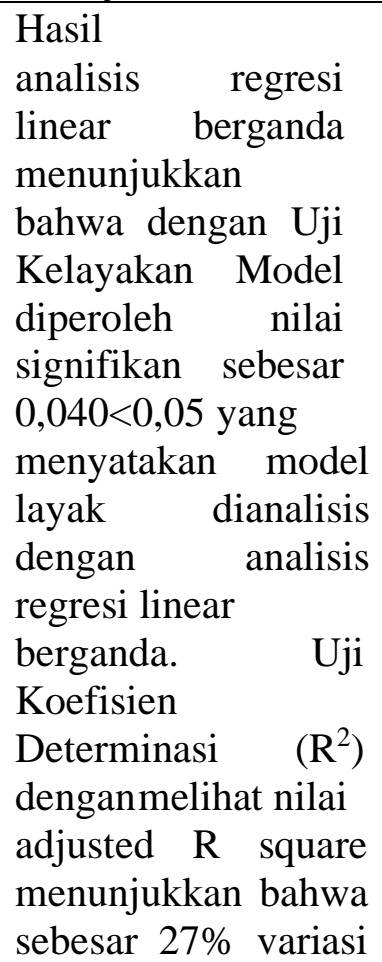 \\
\hline
\end{tabular}




\begin{tabular}{|c|c|c|c|c|c|}
\hline & & & & & $\begin{array}{l}\text { variabel dependen } \\
\text { dalam penelitian ini } \\
\text { dapat dijelaskan oleh } \\
\text { variasi dari variabel } \\
\text { dependen. }\end{array}$ \\
\hline 24 & $\begin{array}{l}\text { Emy Puji } \\
\text { Puspitasari, } \\
\text { dkk/2019 }\end{array}$ & $\begin{array}{l}\text { Pengaruh } \\
\text { Faktor } \\
\text { Good Good } \\
\text { corporate } \\
\text { governance } \\
\text {, Free Cash } \\
\text { Flow, dan } \\
\text { Laverage } \\
\text { Terhadap } \\
\text { Manajemen } \\
\text { Laba Pada } \\
\text { Perusahaan } \\
\text { Batu Bara }\end{array}$ & $\begin{array}{l}\text { untuk } \\
\text { mengetahui } \\
\text { pengaruh } \\
\text { faktor good } \\
\text { good } \\
\text { corporate } \\
\text { governance, } \\
\text { free cash flow, } \\
\text { dan leverage } \\
\text { terhadap } \\
\text { manajemen } \\
\text { laba }\end{array}$ & $\begin{array}{l}\text { analisis } \\
\text { regresi } \\
\text { linier } \\
\text { berganda. }\end{array}$ & $\begin{array}{l}\text { Hasil analisis } \\
\text { menunjukkan bahwa } \\
\text { secara parsial dewan } \\
\text { komisaris } \\
\text { independen, ukuran } \\
\text { komite audit, } \\
\text { kepemilikan } \\
\text { institusional, } \\
\text { leverage, dan free } \\
\text { cash flow terhadap } \\
\text { manajemen laba } \\
\text { berpengaruh positif } \\
\text { dansignifikan, } \\
\text { kepemilikan } \\
\text { manajerial tidak } \\
\text { mempunyai } \\
\text { pengaruh terhadap } \\
\text { manajemen laba. }\end{array}$ \\
\hline 25 & $\begin{array}{l}\text { Viola Syukrina E } \\
\text { Janrosl dan } \\
\text { Joyce Lim/2019 }\end{array}$ & $\begin{array}{l}\text { Analisis } \\
\text { Pengaruh } \\
\text { Good } \\
\text { Good } \\
\text { corporate } \\
\text { governan } \\
\text { ce } \\
\text { Terhadap } \\
\text { Manajem } \\
\text { en Laba } \\
\text { Pada } \\
\text { Perusahaa } \\
\mathrm{n} \\
\text { Perbanka } \\
\mathrm{n} \quad \text { yang } \\
\text { Terdaftar } \\
\text { di BEI }\end{array}$ & $\begin{array}{l}\text { Menganalisis } \\
\text { pengaruh } \\
\text { komisaris } \\
\text { independen, } \\
\text { kepemilikan } \\
\text { manajerial, } \\
\text { kepemilikan } \\
\text { institusional } \\
\text { dan komite } \\
\text { audit terhadap } \\
\text { manajemen } \\
\text { laba pada } \\
\text { perusahaan } \\
\text { perbankan } \\
\text { adalah tujuan } \\
\text { penelitian ini. }\end{array}$ & $\begin{array}{l}\text { analisis } \\
\text { regresi } \\
\text { linier } \\
\text { berganda. }\end{array}$ & $\begin{array}{l}\text { Hasil } \\
\text { penelitian ini } \\
\text { Komisaris } \\
\text { Independen } \\
\text { berpengaruh } \\
\text { signifikan terhadap } \\
\text { manajemen } \\
\text { laba. Kepemilikan } \\
\text { Manajerial } \\
\text { berpengaruh } \\
\text { signifikan terhadap } \\
\text { manajemen laba. } \\
\text { Kepemilikan } \\
\text { Institusional tidak } \\
\text { berpengaruh } \\
\text { signifikan terhadap } \\
\text { manajemen laba. } \\
\text { Komite audit } \\
\text { berpengaruh } \\
\text { signifikan terhadap } \\
\text { manajemen laba. } \\
\text { Komisaris } \\
\text { independen, } \\
\text { kepemilikan }\end{array}$ \\
\hline
\end{tabular}




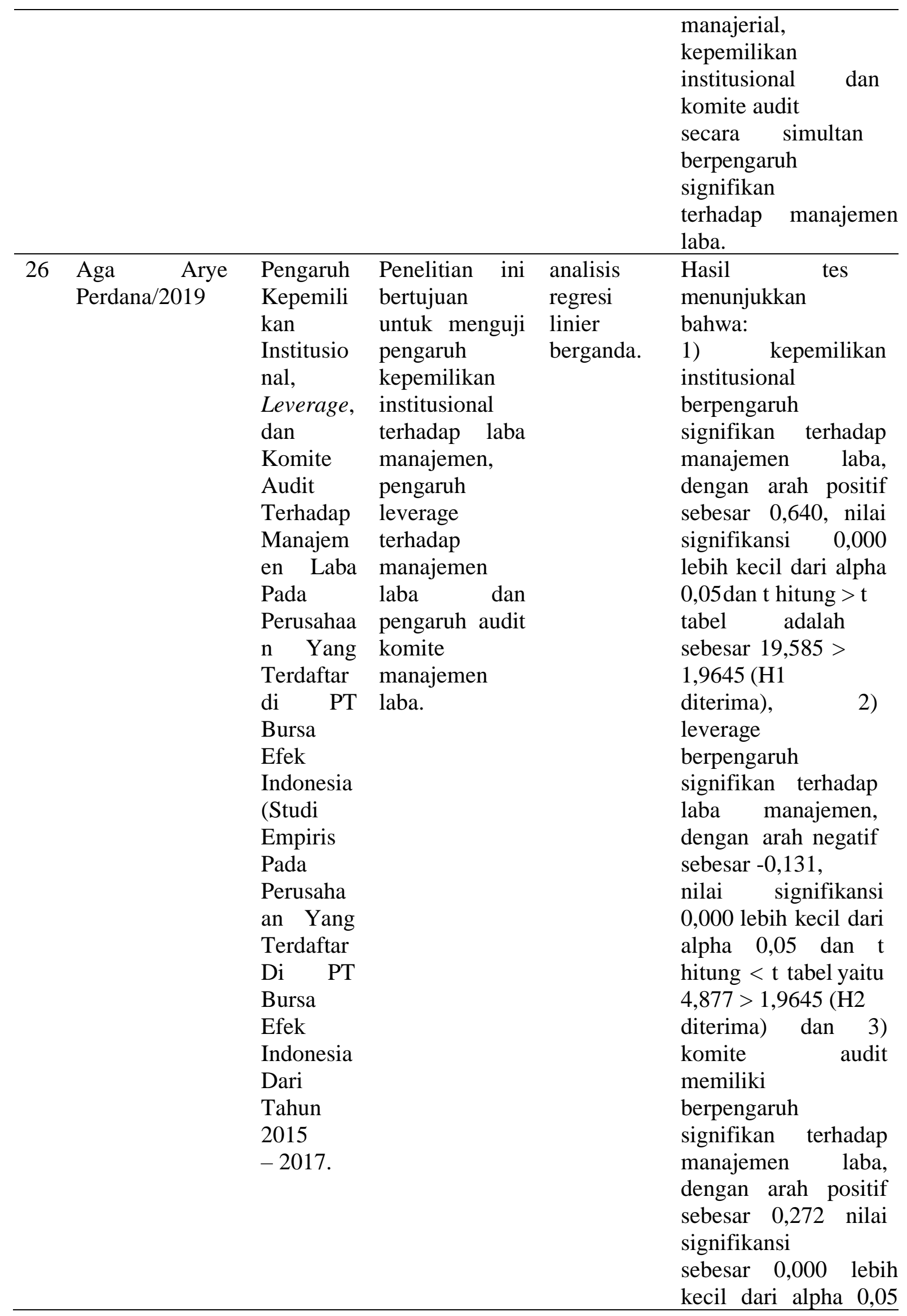




\begin{tabular}{|c|c|c|c|c|c|}
\hline & & & & & $\begin{array}{l}\text { dan nilai } \\
\mathrm{t}, 400>1,9645 \quad(\mathrm{H} 3 \\
\text { adalahditerima). }\end{array}$ \\
\hline 27 & \begin{tabular}{l}
\multicolumn{2}{l}{ Friscasyllia } \\
Lavenia Lolana \\
dan Susi \\
$\begin{array}{l}\text { Dwimulyani/201 } \\
9\end{array}$
\end{tabular} & $\begin{array}{l}\text { Pengaruh } \\
\text { Good Good } \\
\text { corporate } \\
\text { governance } \\
\text { Terhadap } \\
\text { Manajemen } \\
\text { Laba } \\
\text { Dengan Tax } \\
\text { Avoidance } \\
\text { Sebagai } \\
\text { Variabel } \\
\text { Intervening }\end{array}$ & $\begin{array}{l}\text { untuk } \\
\text { mendapatkan } \\
\text { bukti empiris } \\
\text { mengenai } \\
\text { pengaruh good } \\
\text { good } \\
\text { corporate } \\
\text { governance } \\
\text { terhadap } \\
\text { manajemen } \\
\text { laba dengan } \\
\text { tax avoidance } \\
\text { sebagai } \\
\text { variabel } \\
\text { intervening. }\end{array}$ & $\begin{array}{l}\text { analisis } \\
\text { regresi } \\
\text { linier } \\
\text { berganda. }\end{array}$ & 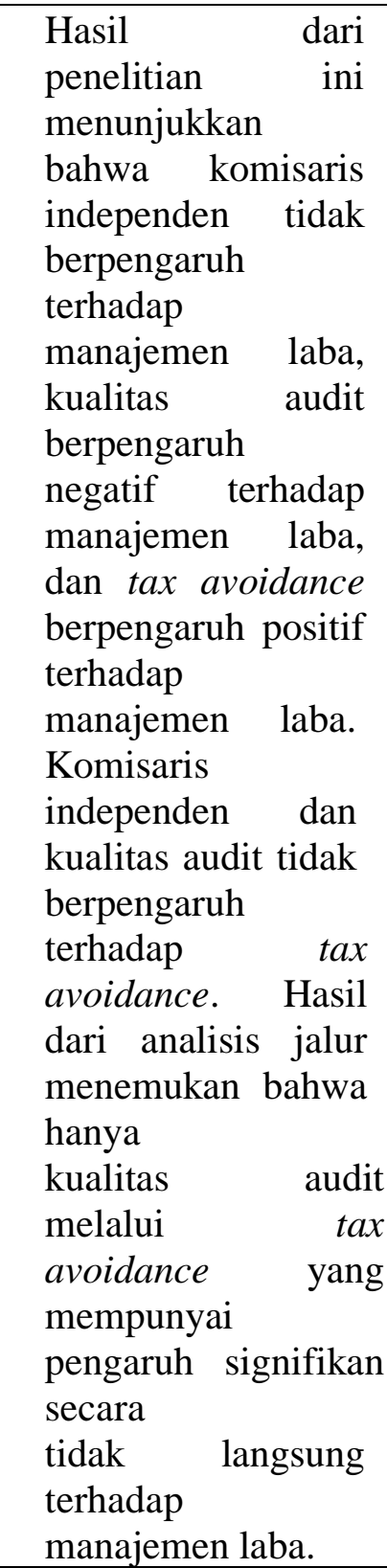 \\
\hline
\end{tabular}




\begin{tabular}{|c|c|c|c|c|c|}
\hline 28 & $\begin{array}{l}\text { Novy } \\
\text { Sulistyoningsih } \\
\text { dan Nur } \\
\text { Fadjrih } \\
\text { Asyik/2019 }\end{array}$ & $\begin{array}{l}\text { Pengaruh } \\
\text { Good Good } \\
\text { corporate } \\
\text { governanc } \\
e \quad \text { dan } \\
\text { Kinerja } \\
\text { Keuangan } \\
\text { Terhadap } \\
\text { Manajeme } \\
\text { n Laba. }\end{array}$ & $\begin{array}{l}\text { untuk menguji } \\
\text { pengaruh good } \\
\text { good } \\
\text { corporate } \\
\text { governance } \\
\text { yang meliputi } \\
\text { kepemilikan } \\
\text { institusional, } \\
\text { kepemilikan } \\
\text { manajerial, } \\
\text { ukuran dewan } \\
\text { komisaris, dan } \\
\text { komite audit } \\
\text { serta kinerja } \\
\text { keuangan yang } \\
\text { diproksikan } \\
\text { dengan Return } \\
\text { On Assets } \\
\text { terhadap } \\
\text { manajemen } \\
\text { laba pada } \\
\text { perusahaan } \\
\text { makanan dan } \\
\text { minuman } \\
\text { yang terdaftar } \\
\text { di Bursa Efek } \\
\text { Indonesia. }\end{array}$ & $\begin{array}{l}\text { analisis } \\
\text { regresi } \\
\text { linier } \\
\text { berganda. }\end{array}$ & $\begin{array}{l}\text { Hasil dari penelitian } \\
\text { ini menunjukkan } \\
\text { bahwa dalam uji F } \\
\text { penelitian ini layak } \\
\text { digunakan yaitu } \\
\text { kepemilikan } \\
\text { institusional, } \\
\text { kepemilikan } \\
\text { manajerial, ukuran } \\
\text { dewan komisaris, } \\
\text { komite audit dan } \\
\text { return on assets } \\
\text { berpengaruh } \\
\text { terhadap tingkat } \\
\text { manajemen laba } \\
\text { dengan sebesar } \\
\text { signifikansi sebes } \\
\text { 0,031. Sedangkan } \\
\text { uji t menunjukkan } \\
\text { bahwa variabel } \\
\text { kepemilikan } \\
\text { institusional } \\
\text { berpengaruh positif } \\
\text { terhadap } \\
\text { manajemen laba. } \\
\text { Variabel } \\
\text { kepemilikan } \\
\text { manajerialtidak } \\
\text { berpengaruh } \\
\text { terhadap akuran } \\
\text { manajemen laba. } \\
\text { Variabel komisaris } \\
\text { dewan tidak berpengaruh } \\
\text { terhadap manajemen } \\
\text { laba dengan variabel }\end{array}$ \\
\hline
\end{tabular}

Berdasarkan 30 artikel di atas, dapat disimpulkan bahwa rata-rata mekanisme good corporate governance tidak memiliki pengaruh terhadap manajemen laba karena di dalam 30 artikel yang dianalisis hanya ada 10 artikel yang mengungkapkan adanya pengaruh good good corporate governance dan tidak semua variabel di good corporate governance memiliki pengaruh positif terhadap manajemen laba seperti hanya kepemilikan manajerial dan komite audit berpengaruh secara signifikan terhadap manajemen laba yang terdapat di dalam penelitian (Syafitri, 2020). Penelitian lain yang mengungkapkan hanya beberapa variabel komposisi dari good corporate governance yang memiliki pengaruh terhadap manajemen laba diataranya penelitian (Wagner, 2020) 
yang mengungkapkan komisaris independen, komite audit dan kepemilikan manajerial berpengaruh signifikan terhadap manajemen laba. Penelitian (Shania, Sanif, \& Alkaf, 2020) juga hanya mengungkapkan bahwa hanya dewan komisaris dan komite audit berpengaruh signifikan terhadap manajemen laba. Penelitian (Camelia \& Maknun, 2021) juga mengungkapkan hanya kepemilikan institusional, ukuran dewan komisaris dan komite audit yang berpengaruh terhadap manajemen laba.

Berdasarkan hal itu, dapat disimpulkan bahwa mekanisme good good corporate governance tidak memiliki pengaruh terhadap manajemen laba, jika memiliki pengaruh terhadap manajemen laba hanya beberapa variabel komposisi dari good corporate governance yang berpengaruh terhadap manajemen laba.

\section{Kesimpulan}

Penelitian ini menggunakan metode penelitian tinjauan/mereview/literatur review yang secara terstruktur untuk mengidentifikasi dan mengetahui bagaimana pengaruh dari mekanisme good corporate governance terhadap manajemen laba. Hasilnya menjelaskan bahwa mekanisme good good corporate governance tidak memiliki pengaruh positif secara signifikan terhadap manajemen laba. Ada beberapa penelitian yang mengungkapkan mekanisme good corporate governance memiliki pengaruh terhadap manajemen laba tetapi hanya beberapa variabel komposisi dari varibel good good corporate governance yang memiliki pengaruh positif. Jadi kami simpulkan bahwa rata-rata pengaruh mekanisme good corporate governance tidak memiliki pengaruh terhadap manajemen laba.

Hasil metode tinjauan atau review yang secara terstruktur memiliki keterbatasan diantaranya total sampel yang digunakan peneliti hanya pada industri manufaktur. Artinya tidak bisa mewakili keseluruhan dari berbagai sektor industri yang terdaftar di BEI dan rentan waktu yang dipakai peneliti hanya terbatas dua tahun. Rentan waktu itu memungkinkan manajemen laba tidak bisa mencerminkan keadaan yang sebenarnya di suatu perusahaan. Berdasarkan keterbatasan hal itu, dapat dijadikan peluang untuk penelitian selanjutnya yaitu dengan menambah sampel berbagai sektor industri lainnya yang sudah terdaftar di BEI misalnya yaitu sektor industri telekomunikasi atau sektor lainnya. Peneliti selanjutnya dapat menambah rentan waktu seperti lima tahun. Hal tersebut dilakukan agar hasil temuan penelitian selanjutnya dapat menggeneralisasi mengenai bagaimana mekanisme good corporate governance terhadap manajemen perusahaan yang sudah terdaftar di BEI. 


\section{BIBLIOGRAFI}

Camelia, Celi, \& Maknun, Lu'luil. (2021). Implementasi problem based learning (PBL) dalam pembelajaran jarak jauh di MI Al-Mursyidiyyah selama masa pandemi. Elementar: Jurnal Pendidikan Dasar, 1(1), 23-37.Google Scholar

Fadhilia, Wida. (2017). Pergantian CEO, Penghindaran Pajak, Kompensasi Eksekutif dan Manajemen Laba Studi Kausalitas pada Perusahaan Manufaktur Indonesia. Syiah Kuala University. Google Scholar

Lu'luilmaknun, Lu, \& Rusli, Devvy. (2021). Pengaruh Kualitas Audit Dan Corporate Governance Terhadap Manajemen Laba (Studi Pada Perusahaan Manufaktur Yang Terdaftar Di Bursa Efek Indonesia Periode 2015-2019). Sekolah Tinggi Ilmu Ekonomi Indonesia Jakarta. Google Scholar

Pramesti, Ellita, \& Rahayu, Yuliastuti. (2021). Pengaruh Corporate Governance, Leverage Dan Kinerja Keuangan Terhadap Manajemen Laba. Jurnal Ilmu Dan Riset Akuntansi (JIRA), 10(6). Google Scholar

Purwanti, Putu Indah, Kepramareni, Putu, \& Pradnyawati, Sagung Oka. (2021). Pengaruh Corporate Governance, Ukuran Perusahaan Dan Leverage Terhadap Manajemen Laba Pada Perusahaan Manufaktur Yang Terdaftar Di Bursa Efek Indonesia Periode 2017-2019. Kumpulan Hasil Riset Mahasiswa Akuntansi (Kharisma), 3(1), 197-206. Google Scholar

Putri, Anandha Sartika. (2021). Pengaruh Karakteristik Perusahaan Terhadap Cash Holding. Jurnal Bina Bangsa Ekonomika, 14(1), 58-69. Google Scholar

Rahmawati, Melai, Dewi, Veni Soraya, \& Hikmah, Siti Noor. (2017). Pengaruh Kualitas Auditor dan Corporate Governance terhadap Manajemen Laba (Studi Empiris pada Perusahaan Manufaktur yang Terdaftar di Bursa Efek Indonesia Periode 2011-2016). URECOL, 459-474. Google Scholar

Ramadhani, Nila, Sari, Ria Nelly, \& Darlis, Edfan. (2015). Pengaruh Karakteristik Dewan KomisarisDan KarakteristikPerusahaan Terhadap Praktik Manajemen Risiko Perusahaan. Jurnal Akuntansi, 4(1), 2337-2431. Google Scholar

Shania, Sarah, Sanif, Rizal, \& Alkaf, Syifa. (2020). Gambaran Tingkat Pengetahuan Ibu Hamil Tentang Kontrasepsi Iud Di Klinik Al-Syifa Palembang. Sriwijaya University. Google Scholar

Sianturi, Juliana, Rangkuti, Salsa Dila Hakim, Siregar, Vallmer Gading Maran, Purba, Leoma Meyana, Gultom, Dicki Maher Henrikus, \& Gultom, Tumiur. (2021). Pemanfaatan Limbah Tempurung Kemiri (Aleurites Moluccana) Menjadi Briket Arang Di Desa Silimalombu. Prosiding Seminar Nasional Pengabdian Kepada Masyarakat" Penguatan Peran Perguruan Tinggi Dalam Meningkatkan Kualitas Hidup Di Era New Normal Melalui Hasil Pengabdian Kepada Masyarakat", 228234. Lembaga Penelitian dan Pengabdian Kepada Masyarakat (LPPM) Universitas. 
Google Scholar

Syafitri, Fadilah. (2020). Pengaruh Good Corporate Governance, Profitabilitas dan Ukuran Perusahaan Terhadap Manajemen Laba pada Perusahaan Manufaktur yang Terdaftar di BEI Periode 2016-2018. Google Scholar

Tarigan, Yudha Pratama. (2021). Perlindungan Hukum Terhadap Pihak Pembeli Tanah Berdasarkan Perjanjian Jual Beli Tanah Yang Penjualnya Wanprestasi (Studi Putusan Nomor: 50/Pdt. G/2018/PN Bnj). Kumpulan Karya Ilmiah Mahasiswa Fakultas Sosial Sains, 2(02). Google Scholar

Wagner, Barbara. (2020). Luigia Sabbatini, Inez Dorothé van der Werf (Eds.): Chemical analysis in cultural heritage. Springer. Google Scholar

Widasari, Ela, \& Sumartono, Sumartono. (2021). Pengaruh Kinerja Keuangan Dan Mekanisme Good Corporate Governance Terhadap Manajemen Laba Pada Perusahaan Manufaktur Sektor Barang Konsumsi Terdaftar Di Bursa Efek Indonesia (BEI). The Asia Pacific Journal Of Management Studies, 8(2). Google Scholar

Yuni Kartika, Nita. (2020). Pengaruh Corporate Governance Terhadap Manajemen Laba (Studi Empiris pada Perusahaan Manufaktur yang Terdaftar di Bursa Efek Indonesia Tahun 2016-2019). Sekolah Tinggi Ilmu Ekonomi Indonesia Jakarta. Google Scholar

\section{Copyright holder:}

Dwi Urip Wardoyo, Rekha Fakhriyah, Risca Amelia (2021)

\section{First publication right:}

Syntax Idea

This article is licensed under: 